\title{
Perlindungan Hukum Bagi Peternak Ayam Broiler dalam Pola Kemitraan Inti Plasma dengan PT Ciomas Adisatwa di Kabupaten Kerinci
}

\author{
Maryati ${ }^{1}$, Putri Anggela Sari \\ Fakultas Hukum Universitas Batanghari Jalan Slamet Riyadi Broni Kota Jambi \\ (0741) 65351
}

\begin{abstract}
Abstrak
Penelitian ini bertujuan untuk mengetahui dan menganalisis implementasi perlindungan hukum terhadap peternak ayam broiler dalam kemitraan pola inti plasma dengan PT Ciomas Adisatwa di Kabupaten Kerinci, untuk mengetahui dan menganalisis masalah-masalah yang terjadi dalam hubungan kemitraan serta untuk mengetahui dan menganalisis upaya yang dapat dilakukan untuk memberikan perlindungan hukum kepada peternak plasma tersebut. PT. Ciomas Adisatwa merupakan perusahaan yang menyelenggarakan kegiatan usaha yang bergerak di bidang pembibitan DOC (Day Old Chickhen) dan memproduksi berbagai jenis obat-obatan dan pakan untuk ternak. Jumlah peternak yang melakukan kemitraan dengan perusahaan ini adalah sebanyak 14 orang peternak. Penelitian ini merupakan penelitian yuridis empiris, yaitu penelitian yang dimaksudkan untuk mengetahui bagaimana pelaksanaan perlindungan hukum terhadap peternak ayam broiler dalam kemitraan dengan PT. Ciomas Adisatwa di Kabupaten Kerinci; apakah telah sesuai dengan peraturan perundang-undangan yang berlaku. Data primer dalam penelitian ini diperoleh langsung dari hasil penelitian lapangan (field research) dengan melakukan wawancara terhadap karyawan PT Ciomas Adisatwa, tenaga pembinaan dan penyuluhan di Dinas Peternakan Kabupaten Kerinci, dan enam (6) orang peternak ayam broiler yang bermitra dengan PT. Ciomas Adisatwa. Hasil penelitian menunjukkan, perlindungan hukum terhadap peternak ayam broiler dalam kemitraan dengan PT. Ciomas Adisatwa di Kabupaten Kerinci belum terpenuhi sepenuhnya. Hak yang sudah terpenuhi dengan baik adalah hak peternak untuk mendapat bimbingan tentang budidaya ayam dari PPL yang diutus oleh pihak inti. Hak untuk mendapatkan saprodi dari pihak inti belum terpenuhi dengan baik karena peternak sering mendapatkan DOC kualitas jelek, pakan dan obat-obatanpun diragukan kualitasnya. Hak untuk mendapatkan jaminan pemasaran memang terpenuhi tetapi harga yang yang ditetapkan pihak inti tidak memuaskan peternak. Sedangkan hak yang belum terpenuhi sama sekali adalah hak untuk ikut serta dalam membuat perjanjian. Masalah-masalah yang terjadi dalam pelaksanaan kemitraan antara peternak plasma dengan PT Ciomas Adisatwa adalah rendahnya harga jual hasil produksi, pembagian kelebihan harga jual tidak ada perhitungan yang jelas peternak plasma hanya diberikan seadanya, resiko gagal panen sepenuhnya dibebankan kepada pihak plasma walaupun penyebab gagal panennya adalah wabah penyakit, sering terlambat panen dan pihak inti tidak melayani protes dari peternak. Upaya yang dapat dilakukan untuk melindungi peternak plasma adalah dengan meningkatkan peran pemerintah yaitu dalam pengawasan, pengawalan dan pembinaan secara berkelanjutan terhadap jalannya kemitraan dan memberikan sanksi yang tegas bagi pihak yang melanggar peraturan kemitraan.
\end{abstract}

Kata kunci : Perlindungan Hukum, Peternak Ayam Broiler, Kemitraan Pola Inti Plasma.

Abstract
This research aims to find out and analyze the implementation of legal protection of chicken
broiler breeders in partnership pattern core plasma with PT Ciomas Adisatwa Kerinci

${ }^{1}$ Dosen Fakultas Hukum Universitas Batanghari Jambi 
Regency, to know and analyze problems that happens in relationships the partnerships as well as to know and analyze the efforts that can be made to give legal protection to the breeder the plasma. Ciomas Adisatwa PT is a company that conducts business activities engaged in the breeding of the DOC (Day Old Chickhen) and produces various types of medicines and fodder for livestock. The number of breeders who do partnership with this company is as much as 14 farmers. This study is an empirical juridical research, i.e. research intended to find out how the implementation of legal protection of chicken broiler breeders in partnership with PT Ciomas Adisatwa. in Kerinci; whether it has been in accordance with the legislation in force. Primary data in this study were obtained directly from the results of the research field (field research) by doing the interview PT Ciomas Adisatwa employee, energy coaching and counseling in Dinas Farm District Kerinci, and six (6) people Chicken broiler breeders who partnered with PT Ciomas Adisatwa.. The results showed, legal protection of chicken broiler breeders in partnership with PT Ciomas Adisatwa. in Kerinci haven't fulfilled completely. A right that is already being met with a good breeder is a right to receive guidance about chicken farming from PPL sent by parties to the core. The right to the core of the saprodi have not been fulfilled so well because breeders often get DOC quality bad, feed and drug-obatanpun doubt its quality. The right to obtain a guarantee of marketing is indeed being met but the price that the parties set out the core of the breeder is not satisfactory. Whereas rights that have not been met at all was the right to participate in the making of the agreement. Problems occurring in the implementation of the partnership between rancher PT Ciomas Adisatwa with plasma is a low selling price of production results, Division of excess selling price of no obvious calculation breeder plasma just given potluck, the risk of failed harvest is fully charged to the plasma though the cause of the failed panennya are disease outbreaks, often late harvest and the core does not serve a protest from a breeder. Efforts that can be done to protect the ranchers plasma is by increasing the Government's role in the supervision, control and sustainable construction against the operations of the partnership and gave strict sanctions for parties breaking the rules of partnership.

Keywords: legal protection, the Chicken Broiler Breeders, partnership Pattern Plasma Core.

\section{PENDAHULUAN}

Usaha kecil merupakan sektor kegiatan ekonomi yang penting dalam ekonomi nasional, karena selain memiliki peranan dalam menjawab tantangan-tantangan pembangunan, yaitu perluasan lapangan kerja bagi angkatan kerja yang terus bertambah jumlahnya, juga untuk peningkatan penghasilan masyarakat secara lebih merata.

Pemerintah juga menyadari peranan usaha kecil dalam pembangunan nasional. Kendati mempunyai peran penting dalam perekonomian nasional, usaha kecil seringkali terhenti di tengah jalan karena keterbatasan-keterbatasan yang dimilikinya. Keterbatasan utama yang dimilikinya adalah keterbatasan modal, keterbatasan pengetahuan, dan keterbatasan akses pemasaran.

Usaha kecil adalah kegiatan ekonomi rakyat yang berskala kecil dan memenuhi kriteria kekayaan bersih atau hasil penjualan tahunan sebagaimana diatur dalam UU Nomor 20 tahun 2008. Pasal 6 UU Nomor 20 tahun 2008 tentang UMKM, menerangkan tentang kriteria UMKM adalah sebagai berikut:

(1) Kriteria Usaha Mikro adalah:

a. memiliki kekayaan bersih paling banyak Rp 50.000.000,00 (lima puluh juta rupiah) tidak termasuk tanah dan bangunan tempat usaha; atau 
b. memiliki hasil penjualan tahunan paling banyak Rp 300.000.000,00 (tiga ratus juta rupiah).

(2) Kriteria Usaha Kecil adalah:

a. memiliki kekayaan bersih lebih dari $\mathrm{Rp} 50.000 .000,00$ (lima puluh juta rupiah) sampai dengan paling banyak $\mathrm{Rp} 500.000 .000,00$ tidak termasuk tanah dan bangunan tempat usaha; atau

b. memiliki hasil penjualan tahunan lebih dari Rp 300.000.000,00 (tiga ratus juta rupiah) sampai dengan paling banyak Rp 2.500.000.000,00 (dua milyar lima ratus juta rupiah)

(3) Kriteria Usaha Menengah adalah sebagai berikut :

a. memiliki kekayaan bersih lebih dari Rp 500.000.000,00 (lima ratus juta rupiah) sampai dengan paling banyak Rp 10.000.000.000,00 (sepuluh milyar rupiah) tidak termasuk tanah dan bangunan tempat usaha; atau

b. memiliki hasil penjualan tahunan lebih dari 2.500.000.000,00 (dua milyar lima ratus juta rupiah) sampai dengan paling banyak Rp. 50.000.000.000,00 (lima puluh milyar rupiah)

Yang dimaksud dengan kekayaan bersih adalah hasil pengurangan total nilai kekayaan usaha (aset) dengan total nilai kewajiban, tidak termasuk tanah dan bangunan tempat usaha. Yang dimaksud dengan hasil penjualan tahunan adalah hasil penjualan bersih (netto) yang berasal dari penjualan barang dan jasa usahanya dalam satu tahun buku ${ }^{2}$ berikut :

Sutojo $\mathrm{dkk}^{3}$ mengatakan bahwa usaha kecil mempunyai ciri-ciri umum sebagai

a. Kegiatan cenderung tidak formal dan jarang yang memiliki rencana usaha ;

b. Struktur organisasi bersifat sederhana ;

c. Jumlah tenaga kerja terbatas dengan pembagian kerja yang longgar;

d. Kebanyakan tidak melakukan pemisahan antara kekayaan pribadi dengan kekayaan perusahaan ;

e. Sistem akutansi kurang baik, bahkan kadang-kadang tidak memilikinya sama sekali;

f. Skala ekonomi terlalu kecil sehingga sukar menekan biaya ;

g. Kemampuan pemasaran cenderung terbatas ;

h. Marjin keuntungan sangat tipis.

Berdasarkan beberapa ciri umum di atas, dapat dilihat bahwa kelemahan usaha kecil selain dipengaruhi oleh faktor keterbatasan modal juga tampak pada kelemahan manajerialnya, yakni; kelemahan pengorganisasian, perencanaan, pemasaran, maupun pada kelemahan akuntansi.

Sangat disayangkan jika usaha kecil yang memiliki peran penting dalam perekonomian nasional ini harus mati karena keterbatasan yang dimilikinya. Untuk itu perlu dilakukan upaya untuk menyelamatkan usaha kecil ini agar tetap eksis dalam perekonomian negara.

\footnotetext{
${ }^{2}$ Penjelasan Pasal 6 UU Nomor 20 Tahun 2008 tentang Kriteria UMKM

${ }^{3}$ Sutojo,dkk. 1994. Profil Usaha Kecil dan Kebijakan Kredit Perbankan di Indonesia: Jakarta: Lembaga Manajemen FE-UI.hal. 4.
} 
Salah satu solusi yang dapat diambil untuk mengatasi masalah ini adalah melalui pola kemitraan yang menghubungkan antara perusahaan besar dengan usaha kecil. Pemerintahpun sangat mendukung kemitraan ini. Melalui UU Nomor 41 tahun 2014 tentang Peternakan dan Kesehatan Hewan, Pasal 31 angka 1, pemerintah menganjurkan peternak untuk melakukan kemitraan usaha dengan pihak lain berdasarkan perjanjian yang saling menguntungkan dan berkeadilan.

Pasal 1 angka 1 PP Nomor 44 tahun 1997 tentang Kemitraan, mendefenisikan kemitraan adalah kerjasama usaha antara usaha kecil dengan menengah dan atau usaha besar disertai pembinaan dan pengembangan oleh usaha menengah dan atau usaha besar dengan memperhatikan prinsip saling memerlukan, memperkuat dan saling menguntungkan.

Contoh pola kemitraan yang cukup berkembang saat ini adalah kemitraan antara perusahaan pakan ternak dengan peternak ayam. Pola kemitraan yang terjadi adalah inti plasma, dimana perusahaan pakan ternak berperan sebagai inti dan peternak sebagai plasma. Pembentukan plasma ini merupakan suatu kebijakan pemerintah, dimana setiap breeding farm yang akan memperoleh izin usaha, mempunyai kewajiban untuk membangum pola kemitraan dengan peternakan rakyat.

Hubungan kemitraan ini dapat mengatasi kendala pendanaan maupun masalah kualitas produk di tingkat peternak, kemitraan juga dapat menjamin pemasaran maupun tingkat harga hasil produksi peternak. Bukan hanya peternak saja yang mendapat keuntungan, perusahaan inti juga mendapat manfaat yang besar, antara lain mereka dapat memasarkan produknya kepada plasma mitra mereka.

Pada pelaksanaan pola kemitraan antara inti dan plasma ini perlu lebih dicermati pola hubungan antar mitra, sebab secara umum pola kemitraan ini mempertemukan dua kepentingan yang sama tetapi dilatarbelakangi oleh kemampuam manajemen, pemahaman hukum serta pemodalan yang berbeda sehingga plasma sangat rentan menjadi korban dari perusahaan inti yang jelas-jelas mempunyai latar belakang lebih kuat, baik dari segi pemodalan, kemampuan manajemen maupun pemahaman hukum.

Meskipun pemerintah telah melakukan berbagai kebijakan yang dapat membantu peternak plasma, tetapi pada kenyataanya pola kemitraan yang terjadi seringkali merupakan perjanjian standar atau baku, dimana peternak plasma tidak mempunyai kebebasan untuk merundingkan isi perjanjian tersebut. Peternak plasma hanya menerima formulir perjanjian yang disodorkan oleh perusahaan inti untuk disetujui, tanpa punya kesempatan untuk negosiasi atas syarat-syarat yang diajukan oleh perusahaan inti.

Kedudukan plasma sangat lemah karena mereka hanya mempunyai pilihan menerima atau menolak isi perjanjian yang disodorkan perusahaan inti. Apabila peternak menerima perjanjian tersebut, mereka harus siap dengan segala konsekuensi yang ada dan timbul sebagai akibat dari perjanjian tersebut, tetapi apabila peternak menolak maka mereka akan kehilangan kesempatan untuk mengembangkan usaha yang dimiliknya. Pilihan yang sulit ini membuat peternak plasma terjebak dalam hubungan kemitraan yang kurang menguntungkan.

Kondisi di atas juga dialami oleh para peternak ayam potong/broiler di Kabupaten Kerinci. Keterbatasan modal dan keterbatasan pengetahuan membuat 
mereka tidak mempunyai pilihan saat perusahaan inti mengajukan lembar kontrak perjanjian yang telah dibuat sebelumnya. Dalam perjanjian tersebut, perusahaan inti telah menentukan setiap butir yang ada dalam perjanjian yang harus disetujui oleh peternak. Peternak menerima perjanjian kemitraan yang ditawarkan oleh perusahaan inti tersebut karena merupakan satu-satunya jalan untuk mengatasi masalah permodalan mereka.

Para peternak ayam broiler di Kerinci melakukan hubungan kemitraan dengan Perusahaan Ciomas Adisatwa. Jumlah peternak yang bermitra dengan perusahaan ini adalah 14 orang peternak. Berdasarkan survey awal yang penulis lakukan pada kemitraan antara para peternak dan PT Ciomas Adisatwa di Kerinci, penulis menemukan bahwa di satu sisi perusahaan ini banyak membantu peternak plasma dalam hal permodalan, karena perusahaan inti membantu menyediakan sarana produksi seperti seperti bibit (DOC), pakan dan obat-obatan. Selain itu perusahaan inti juga memberikan bimbingan kepada peternak cara beternak ayam yang baik, cara pemeliharaan, cara memberikan obat-obatan dan pakan. Sedangkan peternak plasma hanya menyediakan kandang dan tenaga pemeliharaan sampai ayam siap panen. Pemasaran hasil panen pun dilakukan oleh perusahaan inti.

Tetapi disamping membantu, perusahaan inti sekaligus juga memberikan masalah yang terasa menekan peternak plasma. Antara lain dalam penetapan harga jual hasil panen. Yang berhak menetapkan harga adalah perusahaan inti, peternak tidak bisa negosiasi tentang harga jual tersebut walaupun harga yang ditetapkan terasa merugikan peternak. Kalau peternak protes, perusahaan inti hanya menyodorkan dua pilihan kepada peternak: menerima harga jual yang ditetapkan atau memutuskan hubungan kerjasama dengan perusahaan inti.

Pilihan yang disodorkan oleh perusahaan inti tentu sangat menyudutkan peternak plasma. Peternak plasma mau tidak mau hanya bisa menerima harga yang ditetapkan oleh perusahaan inti. Dalam arti kata, peternak harus tetap menjual hasil panennya kepada perusahaan inti walaupun harus dijual dengan harga yang sangat murah atau memilih pilihan kedua; memutuskan hubungan kerjasama dengan perusahaan inti.

Memutuskan hubungan kerjasama berarti menderita kerugian sebesar Rp 80.000.000.00 - Rp 100.000.000.00, yang telah dikeluarkan untuk biaya pembuatan kandang dan peralatan lainnya. Jumlah uang tersebut bukanlah jumlah yang kecil bagi peternak plasma, dan uang tersebut didapat dengan cara meminjam dari pihak lain. Sungguh kedua pilihan yang disodorkan oleh perusahaan inti ini adalah pilihan yang sangat sulit yang harus tetap dipilih oleh peternak plasma ini.

Posisi peternak plasma yang lemah ini belum mendapatkan perhatian yang serius dari pihak Pemerintah Kabupaten Kerinci. Seharusnya Pemerintah Kabupaten Kerinci mengambil kebijakan untuk menolong peternak plasma yang ada di daerahnya. Tetapi dari survey awal yang penulis lakukan, terlihat bahwa peternak plasma yang ada di Kabupaten Kerinci memang cederung bekerja sendiri, tanpa melibatkan pihak pemerintah dalam hal menjalin kerjasama dengan perusahaan inti.

Berdasarkan uraian di atas, maka penulis tertarik untuk meneliti bagaimana perlindungan hukum terhadap peternak plasma dalam hubungan kemitraan dengan PT Ciomas Adisatwa, yang dirumuskan sebagai berikut: 
1. Apakah perjanjian kemitraan antara peternak plasma dengan perusahaan inti PT Ciomas Adisatwa di Kerinci memberikan perlindungan hukum kepada peternak?

2. Permasalahan-permasalahan apa saja yang sering muncul dalam pola kemitraan tersebut?

3. Upaya apa yang dapat dilakukan untuk memberikan perlindungan hukum kepada peternak plasma di Kerinci dalam hubungan kemitraannya dengan PT Ciomas Adisatwa?

\section{METODE PENELITIAN}

\section{Lokasi Penelitian}

Penelitian ini dilakukan di Kabupaten Kerinci. Pemilihan lokasi penelitian dengan pertimbangan bahwa di Kabupaten Kerinci banyak terdapat peternak ayam broiler yang melakukan kemitraan dengan PT Ciomas Adisatwa.

\section{Tipe Penelitian}

Dalam penelitian ini penulis menggunakan metode penelitian yang bersifat deskriptif analis. Deskriptif artinya penelitian ini menggambarkan tentang kenyataan yang ditemukan di lapangan secara lengkap dan jelas. Hasil penelitian kemudian dianalisa berdasarkan teori-teori atau konsep-konsep yang disimak dalam penelitian.

\section{Pendekatan Penelitian}

Pendekatan yang digunakan dalam penelitian ini adalah pendekatan Yuridis Empiris, yaitu pendekatan yang digunakan untuk melihat aspek-aspek hukum dalam interaksi sosial di dalam masyarakat ${ }^{4}$.

Pada penelitian ini, pendekatan dilakukan dengan cara mempelajari ketentuan hukum yang menyangkut tentang kemitraan pola inti plasma dan melihat bagaimana pelaksanaannya pada kemitraan pola inti plasma antara peternak ayam broiler dan PT Ciomas Adisatwa di Kabupaten Kerinci.

\section{Sumber Data}

\section{Penelitian Perpustakaan}

Yaitu data yang diperoleh dari penelitian kepustakaan, meliputi peraturan perundang-undangan yang berlaku yang berkaitan dengan penelitian ini dan literaturliteratur atau bacaan ilmiah yang berkenaan dengan penulisan skripsi ini.

\section{Penelitian Lapangan}

Yaitu data yang diperoleh langsung dari hasil penelitian lapangan melalui sampel responden. Pengumpulan data di lapangan ini dilakukan dengan cara observasi dan wawancara.

\section{Metode Penetapan Sampel/Informasi}

Penetapan sampel akan dilakukan secara Purposive Sampling, yaitu penetapan sampel dengan memilih beberapa sampel tertentu yang dinilai sesuai dengan tujuan

\footnotetext{
${ }^{4}$ Zainudin Ali. 2009. Metode Penulisan Hukum. Jakarta : Sinar Grafika. hal. 175
} 
atau masalah penelitian dalam sebuah populasi ${ }^{5}$. Penetapan sampel penelitian dengan pertimbangan bahwa sampel yang dipilih adalah sampel yang representatif, yang akan dapat menjawab permasalahan yang penulis ajukan kepadanya. Adapun sampel respondennya adalah :

a. Pimpinan / Karyawan PT Ciomas Adisatwa

b. Pejabat Dinas Peternakan Kabupaten Kerinci yang menangani masalah pembinaan peternakan rakyat.

c. Peternak Plasma

\section{Analisis Data}

Setelah data yang diperoleh dari hasil kepustakaan dan lapangan terkumpul, maka data tersebut penulis analisa secara kualitatif yang mana analisa tersebut dilakukan secara mendalam tentang hal-hal yang berkaitan dengan objek penelitian sehingga diperoleh suatu hasil kesimpulan yang induktif yaitu kesimpulan yang diambil dari hal-hal khusus dan diarahkan kepada kesimpulan yang umum. Kemudian ditarik kesimpulan yang deduktif, yaitu mengambil kesimpulan dari yang umum tersebut menjadi yang khusus atau spesifikasi dari permasalahan yang diteliti.

\section{HASIL DAN PEMBAHASAN}

\section{Perlindungan Hukum Bagi Peternak dalam Perjanjian Kemitraan dengan PT Ciomas Adisatwa}

Sebelum berbicara tentang perlindungan hukum terhadap peternak plasma, penulis akan menguraikan lebih dulu tentang latar belakang peternak plasma tersebut. Jumlah peternak yang bermitra dengan PT Ciomas Adisatwa adalah sebanyak 14 orang peternak. Dari 14 peternak yang bermitra dengan PT Ciomas Adisatwa, penulis mengambil sebanyak 6 peternak untuk menjadi sampel. Untuk lebih jelasnya datadata tentang peternak sampel dapat dilihat pada tabel di bawah ini :

Tabel 1

Peternak Sampel dalam Kemitraan Inti Plasma

\begin{tabular}{clcccl}
\hline No & Nama Peternak & Umur & Pendidikan & Populasi Ayam & \multicolumn{1}{c}{ Alamat } \\
\hline 1 & Zurman Yunus & 60 & SMA & 3000 & Desa Sungai Tutung \\
2 & Kasmira & 42 & SMA & 3000 & Desa Sungai Tutung \\
3 & Karmila & 40 & SMA & 5000 & Desa Sungai Tutung \\
4 & Holidin & 40 & SMA & 5000 & Desa Pulau Tengah \\
5 & Harun & 51 & D3 & 3000 & Desa Cupak \\
6 & Marjana & 55 & SMP & 5000 & Desa Sanggaran Agung \\
\hline
\end{tabular}

Berdasarkan hasil wawancara dengan keenam sampel responden diperoleh data bahwa perusahaan inti yang menjadi mitra usaha mereka mempunyai latar belakang usaha penyediaan sarana produksi peternakan baik itu bibit (DOC), pakan, obat-obatan maupun peralatan peternakan. Sehingga kemitraan yang mereka tawarkan pada peternak akan berdampak secara langsung pada pemasaran hasil

\footnotetext{
${ }^{5}$ Sugiyono. 2010. Metode Penulisan Kualitatif dan Kuantitatif. Bandung. Alfabeta. hal. 61
} 
produksi mereka, yang berarti dengan membangun pola kemitraan tersebut, perusahaan telah membangun pasar tetap bagi produk-produk yang mereka hasilkan. Hal ini merupakan salah satu keuntungan yang diperoleh perusahaan inti dengan melaksanakan perjanjian kemitraan dengan pola inti plasma.

Sedangkan bagi peternak, kemitraan yang ditawarkan akan membantu mengatasi masalah permodalan mereka, karena perusahaan inti memberikan pinjaman berbagai sarana produksi kepada peternak mulai dari bibit ayam DOC (Day Old Chicken), pakan, sampai obat-obatan. Pada kemitraan dengan pola inti plasma ini peternak plasma hanya menyediakan kandang, tenaga pemelihara dan memelihara ayam sampai siap panen.

Dari wawancara dengan sampel responden tersebut dapat pula diketahui bahwa PT Ciomas Adisatwa mempunyai latar belakang yang kuat di bidang permodalan, sumber daya manusia (SDM) dan managemen usaha. Sebaliknya, para peternak plasma mempunyai latar belakang yang lemah di bidang permodalan, sumber daya manusia dan manajemen, sehingga secara hukum kedudukan mereka tidak seimbang saat melakukan perjanjian kemitraan. Ketidakseimbangan kedudukan ini bukannya tidak disadari oleh peternak plasma itu sendiri, tetapi mereka tidak mempunyai pilihan lain untuk mengatasi masalah permodalan dan penyediaan sarana produksi.

Kesepakatan antara perusahaan inti dan peternak plasma dalam melakukan kerja sama pemeliharaan ayam potong/broiler dituangkan dalam bentuk perjanjian kerja sama yang selanjutnya dalam pelaksanaannya ada Surat Kesepakatan yang merupakan tambahan (addendum) dari perjanjian kerja sama tersebut dan merupakan bagian yang tidak terpisahkan dari perjanjian. Surat kesepakatan tersebut bersifat periodik karena selalu berubah setiap satu periode panen sesuai dengan kondisi pasar yang ada. Pada intinya Surat Kesepakatan tersebut berisi tentang:

1. harga bibit ayam (DOC),

2. harga vaksin,

3. harga obat-obatan,

4. harga pakan,

5. harga dasar ayam siap jual,

6. bonus yang diterima peternak plasma apabila hasil panen bagus

7. sanksi yang diterima pihak peternak plasma apabila hasil panen di bawah standar.

Semua point-point dalam Surat Kesepakatan tersebut termasuk penentuan seluruh harga sarana produksi dan ayam siap jual ditentukan oleh perusahaan inti, peternak plasma hanya tinggal menandatanganinya. Surat perjanjian yang telah dibuat dan disiapkan oleh perusahaan inti tersebut merupakan bentuk dari perjanjian standar, dimana pihak plasma tidak mempunyai kesempatan untuk melakukan tawar menawar terhadap isi perjanjian.

Untuk mengkaji perlindungan hukum dalam kemitraan inti plasma sangat dibutuhkan suatu kejelasan peranan masing-masing pihak yang terlibat dalam kemitraan tersebut. Dengan demikian diharapkan terukur seberapa jauh pihak-pihak yang terkait telah menjalankan tugasnya. Peranan dari pelaku kemitraan sebagaimana tertuang dalam Peraturan Pemerintah Nomor 44 Tahun 1997 adalah sebagai berikut :

(a) Peranan Inti 
Pihak inti melaksanakan pembinaan dan pengembangan kepada pihak plasma dalam hal :

1. Menyusun rencana usaha dengan plasma mitranya untuk disepakati bersama.

2. Memberikan bimbingan dalam meningkatkan kualitas SDM plasma, baik melalui pendidikan, pelatihan dan pemagangan dalam bidang kewirausahaan, manajemen, dan keterampilan produksi.

3. Memberikan bimbingan teknologi kepada plasma mitranya.

4. Memberikan pelayanan dan penyediaan sarana produksi untuk keperluan usaha bersama yang disepakati.

5. Menjamin pembelian hasil produksi sesuai dengan kesepakatan yang telah disepakati bersama,

6. Promosi hasil produksi untuk mendapatkan pasar yang baik.

7. Pengembangan teknologi yang mendukung pengembangan usaha.

(b) Peranan Plasma

Dalam melaksanakan kemitraan usaha, plasma didorong untuk melakukan:

1. Bersama-sama dengan inti mitranya melakukan penyusunan rencana untuk disepakati.

2. Menerapkan teknologi dan melaksanakan ketentuan sesuai kesepakatan dengan inti

3. Melaksanakan kerjasama antar sesama plasma yang memiliki usaha sejenis dalam rangka mencapai skala usaha ekonomi untuk mendukung kebutuhan hasil produksinya.

4. Mengembangkan profesionalisme untuk meningkatkan kemampuan atau keterampilan teknis produksi dan usaha.

Perlindungan hukum terhadap peternak plasma pada hakikatnya adalah perlindungan terhadap hak-hak peternak plasma dalam kemitraan, diawali dengan pembuatan perjanjian sampai dengan kegiatan pasca produksi. Dari uraian di atas dapat disimpulkan bahwa hak-hak peternak plasma tersebut meliputi :

\section{Hak dalam membuat perjanjian}

Perjanjian kemitraan antara PT. Ciomas Adisatwa dengan peternak plasma adalah perjanjian baku dimana seluruh klausul dalam perjanjian ditetapkan oleh pihak PT. Ciomas Adisatwa termasuk klausul-klausul di dalam Surat Kesepakatan. Peternak plasma tidak diberi hak sama sekali untuk ikut serta dalam membuat isi Surat Perjanjian dan Surat Kesepakatan tersebut. Hal ini tentu saja bertentangan dengan hukum, karena hak peternak plasma untuk ikut serta dalam membuat surat perjanjian telah diatur dalam peraturan perundangan-undangan. Hak peternak plasma untuk ikut serta dalam membuat perjanjian dapat dilihat dalam:

(1) Pasal 36 ayat (1) UU Nomor 20 tahun 2008 tentang UMKM :

Dalam melaksanakan kemitraan sebagaimana dimaksud dalam pasal 26 para pihak mempunyai kedudukan hukum yang setara dan terhadap mereka berlaku hukum Indonesia.

Pasal tersebut menjelaskan bahwa antara pihak inti dan pihak plasma mempunyai kedudukan yang setara. Ini berarti bahwa pihak inti dan pihak plasma sama-sama 
sebagai subyek hukum yang dapat melakukan perbuatan hukum, sama-sama mempunyai hak dalam menentukan isi perjanjian.

(2) Pasal 4 ayat (3) Surat Keputusan Menteri Pertanian Tahun 1996 tentang Petunjuk Pelaksanaan Pembinaan Usaha Peternakan Ayam Ras :

Perusahaan yang akan melakukan kemitraan harus membuat rencana kerja bersama yang akan dijadikan pedoman penyusunan kontrak.

Isi pasal ini juga mengisyaratkan bahwa pihak plasma juga mempunyai hak untuk ikut menentukan isi perjanjian kemitraan yang dibuat.

(3) Selanjutnya Pasal 19 Peraturan Pemerintah Nomor 44 Tahun 1997 tentang Kemitraan menyebutkan:

Menteri dan menteri teknis memberikan bimbingan atau bantuan lainnya yang diperlukan usaha kecil bagi terselenggaranya kemitraan.

Dalam penjelasan pasal tersebut dikatakan bahwa :

Bimbingan dan bantuan tersebut meliputi antara lain penyusunan perjanjian dan persyaratannya

Pasal 19 ini menyebutkan tentang peran pemerintah dalam membantu dan memfasilitasi pelaksanaan kemitraan bagi pengusaha kecil. Dalam penjelasannya disebutkan bahwa bimbingan dan bantuan tersebut meliputi antara lain penyusunan perjanjian dan persyaratannya. Penjelasan pasal 19 tersebut mengindikasikan bahwa peternak berhak untuk ikut menyusun perjanjian bahkan berhak untuk mendapatkan bimbingan dari pihak pemerintah saat menyusun perjanjian tersebut.

Berdasarkan hasil wawancara penulis dengan responden peternak mengungkapkan bahwa peternak tidak terlibat dalam pembuatan perjanjian kemitraan tersebut, juga tidak ada bimbingan dalam penyusunan perjanjian atau persyaratannya karena perjanjian tersebut telah dibuat atau dicetak oleh pihak perusahaan inti. Padahal sesuai dengan Pasal 19 tersebut seharusnya mitra usaha yaitu peternak plasma juga mempunyai hak untuk ikut menentukan isi perjanjian. Hal ini merupakan salah satu penyimpangan dari pelaksanaan Pasal 19 tersebut.

Sampai saat ini kondisi tersebut masih berlangsung, sementara dari pihak pemerintah sendiri sepertinya tidak bisa memberikan jalan keluar agar aspirasi peternak plasma dapat terakomodasi dalam perjanjian kerja sama yang mereka tanda tangani.

Peran pemerintah untuk mengawasi dan melindungi peternak plasma yang belum nampak implementasinya ditambah lagi dengan posisi peternak yang lemah dengan latar belakang pendidikan yang tergolong rendah membuat perusahaan inti lebih leluasa untuk bersikap semaunya. Situasi yang ada cenderung dimanfaatkan oleh perusahaan inti.

Dalam setiap perjanjian kerja sama maupun kesepakatan-kesepakatan yang mereka lakukan dengan plasmanya, perusahaan inti selalu lebih dulu mempersiapkan point-point yang akan disepakati bersama, plasma hanya tinggal menerima blangko perjanjian yang sudah ada isinya dan menandatanganinya. Bahkan surat kesepakatan bersama yang seharusnya diberikan oleh pihak inti di awal periode pemeliharaan, malah sering diberikan di akhir periode (pada saat panen). 
Sebagaimana hasil wawancara penulis dengan Zurman Yunus salah seorang responden peternak, mengungkapkan bahwa:

"Seharusnya peternak mendapatkan kesempatan untuk tawar menawar tentang isi Surat Kesepakatan tersebut karena klausul-klausul dalam Surat Kesepakatan tersebut bukanlah klausul yang dibakukan. Peternak sudah pernah membicarakan hal ini dengan pihak inti, tetapi tidak mendapat respon yang positif. $^{6}$

Perjanjian kemitraan yang dibuat oleh perusahaan inti tersebut, di setiap klausul yang ada di dalamnya mewakili kepentingan dari perusahaan yang membuatnya sedangkan kepentingan plasma cenderung diabaikan. Perjanjian baku memang cenderung menguntungkan pihak pengusaha baik dari segi efisiensi waktu maupun biaya. Tapi sejauh pihak plasma memahami isi perjanjian yang disodorkan oleh pihak inti, maka tidak ada masalah dalam penerapan perjanjian baku tersebut, yang artinya pihak plasma tahu konsekuensi-konsekuensi yang bisa timbul sebagai akibat berlakunya dari perjanjian tersebut.

Tetapi pada praktiknya pihak plasma sedikit sekali memahami isi perjanjian baku/standar yang mereka tandatangani dan mereka tidak memahami sejauh mana jangkauan hukum dari perjanjian yang mereka tanda tangani. Keenam responden yang penulis wawancara memberikan keterangan yang sama, bahwa mereka menandatangani perjanjian kemitraan tersebut hanya dengan sedikit pemahaman terhadap isi perjanjian. Biasanya mereka lebih melihat pada Surat Kesepakatan yang disodorkan oleh perusahaan inti yang berisi tentang harga-harga sarana produksi dan harga jual ayam siap panen, karena bagi mereka point itulah yang paling penting. Pemahaman mereka yang minim terhadap isi perjanjian tersebut membuat mereka tidak bisa berbuat sesuatu apabila di kemudian hari pihak perusahaan inti tidak menepati isi perjanjian. Pada kasus-kasus yang disebabkan salah satu pihak tidak menepati isi perjanjian maka pihak plasmalah yang selalu dirugikan

Keabsahan berlakunya perjanjian baku/standar memang tidak perlu dipersoalkan, tetapi yang perlu dipersoalkan disini apakah perjanjian tersebut tidak bersifat "berat sebelah" dan tidak mengandung klausul yang secara tidak wajar sangat memberatkan bagi pihak lainnya, sehingga perjanjian tersebut merupakan suatu perjanjian yang menindas dan tidak adil.

Dari fakta di atas terlihat jelas bahwa hak peternak plasma untuk ikut serta dalam membuat perjanjian kemitraan tidak diberikan oleh pihak inti. Hal ini terjadi karena posisi plasma yang lemah dari segi ekonomi ditambah lagi dengan tingkat pendidikan yang rendah serta pemahaman tentang hukum yang sangat minim sekali.

\section{Hak mendapatkan saprodi}

Saprodi merupakan faktor penting dalam melakukan budidaya ayam broiler. Saprodi yang digunakan dalam budidaya ayam broiler ini adalah bibit ayam (DOC), pakan, vaksin dan obat-obatan. Dari hasil wawancara penulis dengan keenam responden peternak diketahui bahwa biaya yang harus dikeluarkan oleh peternak untuk membeli saprodi ini sangat besar. Selain itu untuk mendapatkan saprodi ini

\footnotetext{
${ }^{6}$ Wawancara dengan Zurman Yunus, tanggal 25 Desember 2016
} 
juga sangat sulit. Karena saprodi tidak selalu tersedia dalam jumlah yang dibutuhkan oleh peternak dalam waktu yang bersamaan. Tetapi masalah tersebut dapat teratasi dengan melakukan kerjasama kemitraan dengan perusahaan peternakan ${ }^{7}$.

PT Ciomas Adisatwa selalu tepat waktu dalam menyediakan saprodi untuk peternak plasmanya. Sebelum masa pembersihan kandang selesai, biasanya pihak inti sudah menghubungi pihak plasma menanyakan kapan waktu yang diinginkan pihak plasma untuk pengiriman saprodi. Saprodi yang dipesan juga datang tepat waktu dan dalam jumlah yang cukup. Sehingga peternak tidak perlu takut kalau stok pakan dan obat-obatan habis. Jika pakan dan obat-obatan sudah hampir habis, maka peternak dapat menghubungi pihak inti untuk segera mengirimkan saprodi. Biaya transportasi pengiriman saprodi sampai ke lokasi peternakan ditanggung oleh pihak inti. Hal ini membebaskan peternak dari risiko 'saprodi putus', karena akibatnya fatal. Jika ayam tidak makan sehari saja, maka ayam bisa sakit dan ayam sakit biasanya akan menular pada ayam-ayam yang lain.

Jumlah saprodi yang terpakai akan dikalkulasikan pada setiap akhir periode panen, pembayarannya dilakukan dengan memotong langsung dari hasil penjualan ayam yang dilakukan oleh pihak inti. Harga saprodi juga lebih miring dari harga pasar, karena pihak inti menjual pakan dan obat-obatan kepada peternak plasmanya dengan harga distributor. Selisih harga pakan dari pihak inti dengan harga pasar sekitar Rp 200-Rp 300/kg. Jumlah ini memang nampak kecil, tapi bila dikalikan 10 ton maka akan menjadi jumlah yang besar.

Ada satu hal yang dikeluhkan peternak terkait dengan saprodi yang disediakan oleh pihak inti, yaitu tentang kualitas DOC. Awalnya peternak tidak memahami tentang kualitas DOC yang diberikan, tetapi seiring berjalannya waktu peternak semakin bisa menilai kualitas DOC. DOC kualitas jelek akan berkumpul di satu titik dan tidak aktif bergerak, DOC kualitas baik akan aktif bergerak dan lincah, berpencar; tidak berkumpul di satu titik saja.

DOC kualitas jelek akan berdampak pada biaya dan hasil produksi, maksudnya pada saat siap dipanen, bobot ayam kecil padahal jumlah konsumsi pakannya banyak; maksudnya jumlah konsumsi pakannya sama saja dengan ayam sehat.hal ini tentu sangat merugikan peternak. Tetapi peternak tidak bisa protes dan peternak juga tidak bisa mengembalikan atau menukar DOC kualitas jelek tersebut kepada pihak inti, resiko ini harus ditanggung sendiri oleh peternak karena masalah resiko ini termaktub di dalam Surat Perjanjian Kerjasama, yaitu pada Pasal 6 angka 4, yang bunyinya :"Sehubungan dengan perjanjian ini, Pihak Pertama (Plasma) menjamin kepada Pihak Kedua (Inti) akan menanggung seluruh resiko yang mungkin timbul atas Sarana Produksi setelah diterima dari Pihak Kedua".

Dari isi pasal perjanjian di atas dapat terlihat bahwa pihak inti telah mengantisipasi masalah resiko ini. Kalau resiko yang berkaitan dengan hal yang tak terduga setelah saprodi sampai di tangan peternak, maka keinginan pihak inti untuk tidak bertanggung jawab bisa dimaklumi. Tetapi kalau resiko tentang masalah kualitas saprodi jelek, maka sangat tidak adil jika harus peternak yang menanggungnya. Karena ini bukanlah kesalahan peternak, ini murni kesalahan pihak

\footnotetext{
${ }^{7}$ Wawancara dengan Kasmira,Karmila,Holidin,Harun,Marjana dan Zurman Yunus, tanggal 2328 Desember 2016
} 
inti. Karena pihak inti pasti tahu tentang kualitas saprodi yang dikirimnya kepada peternak.

Berdasarkan wawancara dari keenam responden diketahui bahwa masalah mendapatkan DOC kualitas jelek adalah hal yang sering dialami oleh semua peternak plasma. Selain itu, dari hasil wawancara dengan Zurman Yunus, salah seorang responden peternak mengatakan bahwa:

" Karena hasil panen yang terbilang sedikit, atas saran seorang teman saya pernah secara diam-diam menggunakan pakan dan obat-obatan dari seorang sarjana peternakan. Selama satu periode saya tidak menggunakan pakan dan obat-obatan dari pihak inti; saya hanya menggunakan pakan dan obat-obatan dari teman saya tersebut. Hasilnya sangat menggembirakan, hasil produksi naik hingga tiga kali lipat. Pendapatan saya yang sebelumnya hanya berkisar antara Rp 3 juta - Rp 6 juta, meningkat menjadi Rp 14 juta. Kejadian ini membuat saya berpikir tentang kemungkinan kualitas pakan dan obat-obatan yang di dapat dari pihak inti kemungkinan kualitasnya juga jelek."8

Berdasarkan fakta di atas, dapat disimpulkan bahwa hak peternak untuk mendapatkan saprodi tidak terpenuhi dengan baik. Maksudnya, pihak inti memang melakukan kewajibannya untuk menyediakan saprodi bagi peternak, tetapi kualitas DOC sering jelek. Pakan serta obat-obatan pun diragukan kualitasnya sehingga hak peternak untuk mendapatkan saprodi yang berkualitas baik belum terpenuhi.

\section{Hak mendapatkan bimbingan}

Bimbingan yang diberikan oleh pihak inti kepada peternak plasmanya berkaitan dengan proses pemeliharaan ayam. Meliputi cara memelihara ayam dan apa saja yang dibutuhkan dalam pemeliharaan ayam dari hari ke hari. Karena seiring dengan bertambahnya umur ayam maka perlakuan yang diberikan pun akan berubah.

Dari hasil wawancara yang penulis lakukan terhadap responden, diketahui bahwa peternak mendapat bimbingan tentang budidaya ayam ini dari PPL yang diutus oleh pihak inti. PPL datang secara rutin sebulan sekali. Selain itu PPL juga datang saat akan mulai produksi dan saat panen pada setiap periode serta pada saat ada kejadian yang tidak diduga, seperti ayam sakit terserang wabah dan sebagainya. Tugas dari PPL ini adalah :

1. Memberikan pelayanan teknis kepada peternak;

Berupa pemberian pengarahan-pengarahan yang berkaitan dengan proses pemeliharaan ayam, cepat tanggap dalam penanganan masalah di lapangan dan menjalin komunikasi yang baik dengan peternak

2. Memastikan pengiriman DOC/ bibit ayam dan pengiriman sapronak ke kandang sesuai jadwal pengiriman.

3. Pencatatan administrasi kartu kuning;

Yaitu berupa bukti mulai pengiriman DOC/bibit ayam, bukti pengiriman keperluan sapronak selama proses pemeliharaan ayam, bukti kematian ternak selama proses pemeliharaan dan juga hasil panen ternak selama satu periode.

4. Mengawasi perkembangan dan pertumbuhan ayam selama proses pemeliharaan;

\footnotetext{
${ }^{8}$ Wawancara dengan Zurman Yunus, tanggal 25 Desember 2016
} 
5. Kunjungan rutin kepada peternak;

Yaitu berupa pemeriksaan kecukupan sapronak, jumlah penggunaan sapronak dan juga pemeriksaan kondisi kesehatan ayam.

Dari fakta yang ditemukan dapat disimpulkan bahwa hak peternak untuk mendapatkan bimbingan dan pembinaan telah terpenuhi dengan baik.

\section{Hak mendapatkan jaminan pemasaran hasil produksi.}

Salah satu kewajiban pihak inti adalah memasarkan hasil produksi dari peternak yaitu berupa ayam hidup dan sehat. Selain ayam hidup dan sehat, tinja/kotoran ayam juga bisa dijual yang akan digunakan sebagai pupuk oleh petani. Tetapi tinja ayam ini adalah hak peternak. Maksudnya, hasil penjualan tinja ayam sepenuhnya untuk peternak.

Selama ini memang pihak inti yang memasarkan hasil produksi peternakan sesuai dengan yang tercantum dalam surat perjanjian. Hal ini dikarenakan pihak plasma tidak mempunyai akses pemasaran dan karena pihak inti juga bermaksud untuk mendapatkan harga penjualan saprodi yang terpakai oleh peternak dalam satu periode panen.

Dari hasil wawancara dengan peternak, diketahui bahwa pihak inti selalu menjalankan kewajiban dan tanggung jawabnya untuk memasarkan hasil produksi peternakan. Peternak tidak perlu bersusah payah untuk mencari pembeli dan peternak juga tidak perlu kawatir bahwa hasil peternakannya tidak dapat dijual/ dipasarkan.

Tetapi ada beberapa masalah yang timbul terkait pemasaran hasil panen. Peternak tidak punya hak sama sekali dalam menetapkan harga jual hasil panen. Hak penetapan harga jual sepenuhnya berada di tangan pihak inti. Harga jual hasil panen ditetapkan pada lembaran Surat Kesepakatan. Surat kesepakatan ini dibuat pada setiap satu siklus/periode pemeliharaan.

Seandainya harga yang ditetapkan (biasa disebut harga kontrak), tidak terlalu rendah maka peternak tidak akan mempermasalahkannya. Yang menjadi masalah adalah karena harga kontrak terbilang rendah. Maksudnya harga kontrak yang ditetapkan oleh pihak inti mempunyai selisih yang jauh di bawah harga pasar. Dan selisih harga tersebut hanya diberikan seadanya untuk peternak tanpa perhitungan yang jelas dan pasti.

Saat dikonfirmasikan dengan pihak inti, pihak inti mengatakan bahwa penetapan harga jual sudah sepantasnya, karena pihak inti juga telah menjamin harga minimum kepada peternak.Maksudnya jika harga pasar lebih rendah dari harga kontrak, maka pihak inti tetap membayar kepada peternak seharga nilai kontrak. Dalam hal ini peternak tidak dirugikan sama sekali, seharusnya peternak bisa menerima kondisi ini; peternak berada di posisi aman, pihak intilah yang berada di posisi tidak aman karena pihak inti bisa untung tetapi juga bisa rugi. Saat untungpun pihak inti masih membagikan keuntungan kepada peternak plasma ${ }^{9}$.

Menanggapi pernyataan pihak inti tersebut, keenam responden peternak yang penulis wawancarai mengatakan bahwa:

\footnotetext{
${ }^{9}$ Wawancara dengan Royki, Technical Service PT Ciomas Adisatwa, dilakukan 13 Januari 2017
} 
"Yang diinginkan peternak adalah ada perhitungan yang jelas tentang pembagian hasil kelebihan harga jual, maksudnya berapa persen untuk peternak dan berapa persen untuk perusahaan. Tentu saja kami mengharapkan pembagian yang adil karena selisih harga pasar dengan harga kontrak, cukup besar. Dan harga kontrak selalu di bawah harga pasar, jadi boleh dibilang pihak inti akan selalu untung, kerugian sangat jarang terjadi”" ${ }^{\text {. }}$

Dari fakta di atas, dapat dikatakan bahwa hak peternak untuk mendapatkan jaminan pemasaran belum dipenuhi dengan baik oleh pihak inti. Pihak inti memang melakukan kewajibannya untuk memasarkan hasil produksi tetapi hasil penjualan ayam tersebut tidak memuaskan peternak. Hal ini terjadi karena harga yang ditetapkan oleh pihak inti terlalu rendah. Pihak plasma tidak mempunyai hak untuk ikut menetapkan harga jual. Padahal klausul mengenai kontrak harga jual bukan merupakan klausul baku, karena terdapat dalam Surat Kesepakatan yang isinya selalu berubah pada setiap periode panen. Seharusnya peternak plasma bisa menawar harga yang ditetapkan oleh pihak inti tersebut.

Dari uraian di atas dapat dikatakan bahwa perlindungan hukum terhadap hakhak peternak plasma dalam perjanjian kemitraan dengan PT Ciomas Adisatwa belum terlaksana sesuai peraturan yang berlaku. Hal ini disebabkan karena peternak tidak punya kewenangan sama sekali dalam menentukan isi perjanjian.

Pada dasarnya suatu kemitraan dikatakan ideal ialah kemitraan antara Usaha Menengah atau Usaha Besar dengan Usaha Kecil yang dilandasi oleh kesejajaran kedudukan atau mempunyai derajat yang sama bagi kedua belah pihak yang bermitra, tidak ada yang dirugikan dalam kemitraan. Hal ini bisa dimengerti karena prinsip dari kemitraan usaha adalah win-win solution partnership yang ditekankan pada adanya kesetaraan dalam posisi tawar berdasarkan peran masing-masing pihak yang bermitra.

Pengertian mitra disini bersifat dialogis dan saling mengisi, adanya kekurangan pada yang satu akan diisi oleh pihak yang lainnya. Selain itu dalam kemitraan usaha, hubungan kerjasama yang terjadi antara kedua belah pihak (inti plasma) bukan sebatas jalinan bisnis semata yang hanya mengejar keuntungan bagi masing-masing pihak, akan tetapi jiwa dan semangat usaha bersama merupakan bagian yang tidak terpisahkan dari asas kekeluargaan yang di dalamnya terkandung nilai-nilai keadilan, atau dengan kata lain segala usaha/kegiatan dalam kemitraan usaha tidak hanya menonjolkan motif keuntungan pribadi tetapi dimaksudkan pada keuntungan bersama. Hal ini dapat diperhatikan karena kerjasama yang dimaksud adalah kerjasama yang saling membutuhkan, memperkuat dan saling menguntungkan antara pengusaha besar atau menengah dengan pengusaha kecil sebagai mitranya.

Jika dikaji lebih lanjut, sebenarnya tidaklah masalah sekiranya perjanjian yang dibuat adalah perjanjian baku. Hanya saja klausul-klausul dalam perjanjian tersebut seharusnya tidak berat sebelah demi itikad baik untuk memberikan kepastian dan perlindungan hukum terhadap hak peternak plasma. Kontrak perjanjian kemitraan tersebut harus memuat butir-butir kesepakatan secara menyeluruh tentang hak dan

${ }^{10}$ Wawancara dengan Zurman Yunus, Marjana, Kasmira, Karmila, Harun, Holidin, dilakukan tanggal 23-25 Desember 2016 
kewajiban kedua belah pihak untuk memenuhi hak-hak dasar peternak plasma sesuai dengan peraturan perundang-undangan tentang kemitraan inti plasma.

\section{Masalah-masalah dalam Hubungan Kemitraan}

Kemitraan antara peternak ayam broiler di Kerinci dengan PT Ciomas Adisatwa telah dilakukan sejak empat tahun yang lalu. Jumlah peternak plasma yang sempat memuncak pada tahun 2014 menjadi berkurang lebih dari separuhnya yaitu dari 50 peternak plasma (tahun 2014), sekarang hanya tinggal 14 peternak saja yang menjadi plasmanya. Sebanyak 27 peternak pindah ke PT ITM dan sebanyak 9 plasma telah berhenti menjadi peternak.

Peternak plasma yang masih tertinggal ini terpaksa harus tetap bekerja sama dengan PT. Ciomas Adisatwa. Mereka tidak bisa melepaskan diri dari perusahaan intinya karna melepaskan diri berarti harus menutup usahanya dan harus menanggung kerugian sebesar Rp 80.000.000,- - Rp 100.000.000,- karena mereka sudah terlanjur mengeluarkan biaya yang besar untuk investasi kandang dan perlengkapannya. Jumlah uang tersebut bukanlah uang yang kecil bagi mereka dan uang tersebut di dapat dengan cara meminjam dari pihak lain ${ }^{11}$.

Masalah mendasar yang menyebabkan peternak plasma berontak dan sampai memutuskan kerjasama dengan PT Ciomas Adisatwa adalah mereka merasa diperlakukan tidak adil dan mereka merasa tidak mendapatkan pendapatan yang layak dari hubungan kemitraan tersebut. Pendapatan yang diperolehnya dirasakan tidak dapat menutupi kebutuhan hidup keluarganya per bulan, karena mereka tidak mempunyai pekerjaan lain. Sumber penghasilan mereka semata-mata hanya dari usaha peternakan ini saja. Hanya beberapa orang peternak yang mempunyai pekerjaan lain, yaitu sebagai guru SD dan sebagai Kepala Desa. Sementara pihak inti hampir selalu mendapatkan keuntungan dari kelebihan harga jual setiap peternak setiap kali panen.

Masalah-masalah yang dihadapi peternak selama melakukan kemitraan dengan PT Ciomas Adisatwa dapat dilihat pada uraian berikut ini:

Resiko gagal panen hanya ditanggung oleh peternak.

Apabila terjadi kasus yang menyebabkan kegagalan panen maka semua kerugian ditanggung oleh peternak dan peternak tetap harus membayar biaya sarana produksi yang terpakai.

Kalau kegagalan panen disebabkan karena kesalahan dan kecorobohan plasma, maka plasma tidak keberatan untuk bertanggung jawab sepenuhnya. Akan tetapi kegagalan panen yang disebabkan oleh wabah penyakitpun tetap hanya peternak yang harus menanggungnya. Biaya saprodi yang terpakai tetap harus dibayar oleh peternak dengan cara pemotongan pendapatan secara bertahap pada periode-periode berikutnya.

Resiko kerugian yang $100 \%$ ditanggung oleh peternak plasma terasa sangat berat, karena ini berarti bahwa peternak plasma tidak punya pemasukan/penghasilan untuk jangka waktu yang cukup lama.

${ }^{11}$ Hasil Wawancara dengan Ibu Karmila, Ibu Kasmira, Bpk Marjana, Bpk Holidin, Bpk Zurman Yunus, Bpk Harun. Wawancara dilakukan pada tanggal 23-28 Desember 2016 
Rendahnya harga jual hasil panen.

Yang berhak menetapkan harga jual hasil panen adalah perusahaan inti. Peternak tidak punya hak sama sekali untuk menentukan harga jual ataupun menawar harga jual yang telah ditetapkan oleh pihak inti, termasuk menentukan persentase yang diterima peternak dari kelebihan harga jual.

Harga jual yang ditetapkan oleh pihak inti mempunyai selisih yang cukup besar dengan harga pasar. Ini berarti pihak inti memperoleh keuntungan yang besar dari selisih harga tersebut, tetapi pihak peternak hanya diberikan seadanya saja, tanpa perhitungan yang jelas. Hal ini membuat peternak kecewa karena merasa bahwa pembagian keuntungan tersebut sangat tidak adil.

Menurut Royki, Technical Service di PT Ciomas Adisatwa;

"Penetapan harga jual sudah sepantasnya, karena pihak inti juga telah menjamin harga minimum kepada peternak. Dalam hal ini peternak tidak dirugikan sama sekali, seharusnya peternak bisa menerima kondisi ini; peternak berada di posisi aman, pihak intilah yang berada di posisi tidak aman karena pihak inti bisa untung tetapi juga bisa rugi. Saat untungpun pihak inti masih membagikan keuntungan kepada peternak plasma." 12

\section{Sering terlambat panen.}

Waktu panen ditetapkan oleh pihak inti, plasma tidak punya hak sama sekali untuk menolak apabila ayam harus dipanen/ diambil oleh pihak inti walaupun beratnya belum sesuai perjanjian dan plasma juga tidak bisa protes jika pihak inti belum juga panen padahal umur ayam sudah 30 hari dan beratnya sudah mencukupi. Yang sering terjadi adalah terlambat panen.

Berdasarkan hasil wawancara penulis dengan Harun, salah seorang responden peternak, mengungkapkan bahwa:

"Keterlambatan panen menyebabkan kerugian bagi peternak dan keuntungan bagi pihak inti, karena ayam yang sudah berumur di atas 30 hari kebutuhan pakannya semakin banyak tetapi bobotnya tidak bertambah. Peternak terpaksa harus membeli lebih banyak pakan dan obat-obatan untuk ayam tersebut yang berarti harus mengeluarkan biaya ekstra. Namun bagi pihak inti keterlambatan panen berarti keuntungan, karena pihak inti mendapatkan pemasukan ekstra dari permintaan pakan dan obat-obatan yang bertambah banyak." 13

Pihak inti tidak melayani protes dari peternak.

Tidak ada solusi dari perusahaan inti jika peternak meminta kenaikan harga jual. Jika peternak protes, pihak inti hanya memberikan dua pilihan; meneruskan kerjasama atau memutuskan hubungan kerjasama. Hal ini membuat peternak merasa tertekan, karena tidak diberi pilihan yang lebih bijak oleh pihak inti.

Dari uraian di atas dapat terlihat betapa lemahnya posisi peternak plasma. Hal ini disebabkan karena posisi tawar yang tidak seimbang. Akibat dari keadaan yang

\footnotetext{
${ }^{12}$ Wawancara dengan Royki, Technical Service PT Ciomas Adisatwa, dilakukan 13 Januari 2017

${ }^{13}$ Wawancara dengan Harun, salah satu responden peternak. Dilakukan pada tanggal 24 Desember 2016 .
} 
tidak seimbang tersebut adalah munculnya pihak yang dominan yaitu pihak inti. Pihak dominan itu akan berusaha untuk memaksakan kehendaknya agar diterima oleh pihak yang lainnya.

Dominasi pihak inti dapat dilihat dari banyak sekali kewenangan yang dimiliki pihak inti, sementara pihak plasma bisa dikatakan tidak punya kewenangan sama sekali. Pihak intilah yang menentukan semua isi perjanjian baik mengenai hak dan kewajiban masing-masing pihak, jangka waktu pembayaran hasil panen, harga DOC, harga pakan dan lain sebagainya. Selain itu pihak inti juga tidak menanggung resiko apapun, yang menanggung semua resiko hanya pihak plasma. Dan tidak ada juga sanksi untuk pihak inti

Padahal menurut pasal 26 UU Nomor 20 Tahun 2008, antara Pihak Inti dan Pihak Plasma memiliki kedudukan hukum yang setara. Berarti Pihak Inti dan Pihak Plasma adalah sebagai sama-sama subyek hukum yang dapat melakukan perbuatan hukum. Maksudnya pihak inti dan pihak plasma kedudukannya setara (sama-sama mempunyai hak) dalam menentukan isi perjanjian kemitraan, hanya saja hak tersebut tidak diberikan oleh pihak inti.

Dapat disimpulkan bahwa tidak terdapat asas kesetaraan dalam hubungan kemitraan tersebut. Padahal asas kesetaraan dimaksudkan agar program kemitraan dapat memberikan keuntungan yang adil bagi semua pihak, karena kemitraan pada hakikatnya adalah sebuah kerjasama bisnis yang dilakukan berdasarkan prinsip saling memerlukan, saling memperkuat dan saling menguntungkan bagi kedua belah pihak. Berdasarkan prinsip ini seharusnya antara inti dan plasma mempunyai kesetaraan dalam posisi tawar atau posisi tawar menawar yang seimbang. .

\section{Upaya yang Dapat Dilakukan Untuk Melindungi Peternak Plasma}

Pada hakikatnya kemitraan melibatkan tiga pihak, yaitu pihak inti, pihak plasma dan pihak pemerintah. Pemerintah telah mengatur peran masing-masing pihak melalui peraturan perundangan-undangan. Hubungan kemitraan akan berlangsung harmonis jika masing-masing pihak melakukan perannya dengan baik, sesuai dengan peraturan perundang-undangan yang telah ditetapkan pemerintah.

Dari uraian pada bab sebelumnya, dapat dilihat bahwa hubungan kemitraan antara peternak plasma dengan PT Ciomas Adisatwa tidak berlangsung dengan harmonis karena ada pihak yang merasa dirugikan dan merasa diperlakukan dengan tidak adil padahal pihak tersebut telah melakukan peran yang diembankan kepadanya dengan baik. Pihak yang dirugikan ini adalah peternak plasma. Pihak plasma yang seharusnya dibina dan dibimbing pada kenyataannya malah menjadi sasaran empuk dari perusahaan inti yang menjadi mitranya.

Masalah ini berawal dari latar belakang peternak plasma. Peternak plasma mempunyai latar belakang pendidikan yang rendah, pemahaman tentang hukum yang sangat minim, pemahaman tentang hak-haknya sebagai mitrapun bisa dibilang tidak ada. Selain itu peternak mempunyai latar belakang ekonomi yang lemah.

Latar belakang peternak plasma yang serba kekurangan ini bertolak belakang dengan latar belakang mitra usahanya. Dimana pihak inti selaku mitra usahanya merupakan pelaku bisnis di bidang agri food terbesar di Indonesia. Sebagai pelaku 
bisnis raksasa, sudah tentu pihak inti mempunyai kemampuan manajemen yang kuat, modal yang besar serta SDM yang handal.

Perbedaan latar belakang yang sangat jauh ini dan tidak terlibatnya pemerintah dalam hubungan kemitraan ini memicu pihak inti bersikap semena-mena terhadap pihak plasma. Dalam hubungan kemitraan yang terjalin, pihak plasma cenderung diperlakukan sebagai mangsa bukan sebagai mitra. Hubungan kemitraan yang seharusnya menguntungkan kedua belah pihak, pada akhirnya hanya menguntungkan pihak inti saja. Perusahaan inti dengan latar belakang lebih kuat, baik dari modal, SDM dan manajemen menentukan seluruh isi perjanjian, sedangkan peternak plasma hanya dapat menerima saja.

Untuk melindungi peternak plasma dari perlakuan perusahaan inti tersebut, mutlak diperlukan campur tangan pemerintah sesuai dengan kewenangannya.Mulai dari saat akan dimulainya kemitraan yaitu saat akan membuat perjanjian sampai selanjutnya.

Sesuai dengan Peraturan Pemerintah Nomor 44 Tahun 1997 tentang Kemitraan, pemerintah harus membimbing dan mendampingi peternak untuk membuat perjanjian. Dengan adanya pemerintah saat akan memulai perjanjian, perusahaan inti tidak akan bisa memberikan perjanjian baku kepada peternak. Karena pihak pemerintah pasti akan memberikan teguran kepada pihak inti, dan jika pihak inti tidak mengindahkan teguran dari pemerintah maka pihak inti dapat dikenakan sanksi seperti tertera pada Pasal 39 Undang-undang Nomor 20 Tahun 2008, yaitu dicabut izin usaha dan sanksi denda.

Perjanjian dalam pola kemitraan tersebut harus dibuat dengan bentuk perjanjian tertulis yang jelas dan diketahui oleh pihak-pihak terkait seperti Dinas Peternakan setempat selaku pembina peternak. Perjanjian yang dibuat tertulis harus memuat halhal sebagai berikut :

1. Harga dasar sarana produksi dan/atau harga jual ternak serta produk hewan;

2. Jaminan pemasaran;

3. Pembagian keuntungan dan resiko usaha;

4. Penetapan standar mutu sarana produksi, ternak dan produk hewan;

5. Mekanisme pembayaran.

Setelah berhasil membuat perjanjian yang adil maka pemerintah harus melakukan pengawasan yang aktif terhadap jalannya kemitraan. Pengawasan dan pembinaan yang dilakukan akan mencegah adanya indikasi eksploitasi terhadap peternak/plasma. Pelaksanaan regulasi yang telah dibuat pemerintah yang menjadi payung hukum dalam kemitraan, di lapangan perlu pengawalan dan gerakan yang konkrit sehingga dapat berjalan efektif, serta perlu disusun dan dibuat mekanisme yang jelas bagaimana menerapkan regulasi tersebut. Sehingga tujuan kemitraan yang saling menguntungkan, saling memperkuat dan saling berkeadilan dapat terwujud dan dapat dirasakan oleh kedua belah pihak yang bermitra.

Selain itu dinas terkait pemerintah daerah dapat membuat peraturan daerah sehubungan dengan kemitraan. Kebijakan pemerintah yang sudah dibuat harus menjadi pedoman bagi pelaku usaha di bidang peternakan. Terhadap perusahaan peternakan yang melanggar aturan harus ditindak tegas dengan mengusulkan pencabutan izin usahanya kepada bupati/walikota setempat, sesuai dengan Keputusan 
Menteri Pertanian No. 404/Kpts/OT.210/6/2002 tentang Pedoman Perizinan dan Pendaftaran Usaha Peternakan.

Dari sisi peternak harus selalu dilakukan pembinaan dan penyuluhan secara berkelanjutan. Peraturan perundang-undangan pemerintah terkait dengan peternakan dan kemitraan harus disosialisasikan kepada peternak dan perusahaan peternakan.

\section{SIMPULAN}

Berdasarkan pembahasan dari beberapa pokok permasalahan yang telah diuraikan pada bab sebelumnya, maka dapat diambil kesimpulan sebagai berikut:

1. Perlindungan hukum bagi peternak plasma dalam perjanjian kemitraan dengan PT Ciomas Adisatwa belum terlaksana sepenuhnya sebagaimana telah ditetapkan di dalam peraturan perundang-undangan yang berlaku. Perlindungan hukum yang telah dipenuhi oleh perusahaan inti adalah hak peternak untuk mendapatkan bimbingan teknis tentang budidaya ayam broiler. Perlindungan hukum yang belum terpenuhi adalah :

a. Hak untuk membuat perjanjian.

Surat Perjanjian kemitraan antara peternak dan PT Ciomas Adisatwa berbentuk perjanjian baku dimana pihak intilah yang menentukan setiap isi perjanjian, pihak plasma tidak punya hak sama sekali. Demikian juga halnya dalam penetapan isi Surat Kesepakatan yang merupakan lampiran tentang harga DOC, saprodi dan harga jual ayam; peternak juga tidak punya hak untuk negosiasi tentang isi surat tersebut. Hal ini terjadi karena posisi plasma yang lemah dari segi ekonomi ditambah lagi dengan tingkat pendidikan yang rendah serta pemahaman tentang hukum yang sangat minim sekali.

b. Hak untuk mendapatkan saprodi

Hak peternak untuk mendapatkan saprodi tidak terpenuhi dengan baik. Maksudnya, pihak inti memang melakukan kewajibannya untuk menyediakan saprodi bagi peternak, tetapi kualitas DOC sering jelek. Pakan serta obat-obatan pun diragukan kualitasnya sehingga hak peternak untuk mendapatkan saprodi yang berkualitas baik belum terpenuhi.

c. Hak untuk mendapatkan jaminan pemasaran

Hak peternak untuk mendapatkan jaminan pemasaran belum dipenuhi dengan baik oleh pihak inti. Pihak inti memang melakukan kewajibannya untuk memasarkan hasil produksi tetapi hasil penjualan ayam tersebut tidak memuaskan peternak. Hal ini terjadi karena harga yang ditetapkan oleh pihak inti terlalu rendah. Pihak plasma tidak mempunyai hak untuk ikut menetapkan harga jual. Padahal klausul mengenai kontrak harga jual bukan merupakan klausul baku, karena terdapat dalam Surat Kesepakatan yang isinya selalu berubah pada setiap periode panen

2. Masalah-masalah yang terjadi dalam pelaksanaan kemitraan antara peternak plasma dengan PT Ciomas Adisatwa adalah :

a. Rendahnya harga jual hasil produksi.

Penetapan harga jual dilakukan oleh pihak inti. Pihak plasma tidak berhak sama sekali untuk menetapkan harga jual atau menawar harga jual yang telah ditetapkan pihak inti. Padahal tentang penetapan harga jual bukan termasuk 
klausul yang dibakukan. Selain itu harga jual yang ditetapkan oleh pihak inti mempunyai selisih yang jauh di bawah harga pasar.

b. Pembagian kelebihan harga jual tidak ada perhitungan yang jelas, peternak plasma hanya diberikan seadanya.

c. Resiko gagal panen sepenuhnya dibebankan kepada pihak plasma walaupun penyebab gagal panennya adalah wabah penyakit.

d. Sering terlambat panen sampai 10 hari. Keterlambatan panen mendatangkan kerugian bagi peternak plasma dan sebaliknya malah mendatangkan keuntungan bagi pihak inti. Hal ini disebabkan karena ayam yang telah berumur 30 hari (umur siap panen), jika tidak dipanen makannya bertambah banyak tetapi bobotnya tidak bertambah.

e. Pihak inti tidak melayani protes dari peternak.

Tidak ada solusi dari perusahaan inti jika peternak meminta kenaikan harga jual. Jika peternak protes, pihak inti hanya memberikan dua pilihan; meneruskan kerjasama atau memutuskan hubungan kerjasama. Hal ini membuat peternak merasa tertekan, karena tidak diberi pilihan yang lebih bijak oleh pihak inti.

3. Upaya yang dapat dilakukan untuk melindungi peternak plasma adalah dengan meningkatkan peran pemerintah dalam hubungan kemitraan antara peternak plasma dan perusahaan inti. Peran aktif pemerintah tersebut diwujudkan dalam hal-hal berikut:

a. Mendampingi dan membimbing peternak dalam membuat perjanjian kemitraan.

b. Melakukan pengawasan, pengawalan dan pembinaan secara berkelanjutan terhadap jalannya kemitraan.

c. Memberikan penyuluhan secara berkelanjutan kepada peternak dan mensosialisasikan peraturan perundang-undangan pemerintah terkait dengan peternakan dan kemitraan.

d. Membuat peraturan daerah tentang kemitraan

e. Memberikan sanksi yang tegas bagi pihak yang melanggar peraturan kemitraan.

\section{DAFTAR PUSTAKA}

\section{Buku-buku}

Abdulkadir Muhammad. 1990. Hukum Perikatan. Bandung: PT. Citra Aditya Bakti.

Abdulkadir Muhammad. 1992. Perjanjian Baku dalam Praktek Perusahaan Perdagangan. Bandung: PT. Citra Aditya Bakti

Anton M,dkk. 1995. KBBI. Jakarta: Balai Pustaka.

CST Kansil. 1989. Pengantar Ilmu Hukum dan Tata Hukum Indonesia. Jakarta: Balai Pustaka.

J. Satrio. 1992. Hukum Perjanjian. Jakarta: PT Intermasa.

Mariam D.B. 2001. Kompilasi Hukum Perikatan. Bandung: Citra Aditya Bakti.

Mertokusumo Sudikno. 2003. Mengenal Hukum (Suatu Pengantar). Yogyakarta: Liberti.

Muchsin. 2003. Perlindungan dan Kepastian Hukum bagi Investor di Indonesia. Surakarta: Universitas Sebelas Maret.

Muktie, A.Fajar. 2000. Perlindungan Hukum. Jakarta: Rajawali Pers. 
Philipus M. Hadjon. 1987. Perlindungan Hukum Bagi Rakyat Indonesia. Surabaya: Bina Ilmu

Prodjodikoro, W. 1993. Azas-azas Hukum Perjanjian. Bandung: Sumur Bandung.

Raharjo Satjipto.2000. Ilmu Hukum. Bandung: PT. Citra Aditya Bakti.

Subekti. 2001. Hukum Perjanjian. Jakarta: Intermasa.

Sugiyono. 2010. Metode Penelitian Kualitatif dan Kuantitatif. Bandung: Alfabeta.

Sutojo dkk. 1994. Profil Usaha Kecil dan kebijakan Kredit Perbankan di Indonesia. Jakarta: Lembaga Manajemen FE-UI.

Syahderi, SR. 1993. Kebebasan Berkontrak dan Perlindungan yang Seimbang bagi Para Pihak dalam Perjanjian Kredit di Bank Indonesia. Jakarta: Institusi Bankir Indonesia.

Zainudin Ali.2009. Metode Penelitian Hukum. Jakarta: Sinar Grafika

\section{Peraturan Perundang-undangan}

Undang-undang Hukum Perdata

Undang-undang Nomor 20 tahun 2008 tentang UMKM

Undang-undang Nomor 41 tahun 2014 tentang Peternakan dan Kesehatan Hewan

Peraturan Pemerintah RI Nomor 44 Tahun 1997 tentang Kemitraan.

Keputusan Menteri Pertanian No. 404/Kpts/OT.210/6/2002 tentang Pedoman

Perizinan dan Pendaftaran Usaha Peternakan

SK Mentan No 472 tahun 1996 tentang Petunjuk Pelaksanaan Pembinaan Usaha Peternakan Ayam Ras

\section{Internet/webside}

http://tesishukum.com/pengertian-perlindungan-hukum-menurut-para-ahli/ diakses tanggal 14 Okt0ber 2016

http://hukumonline.com/ asas-asas-perjanjian / diakses tanggal 14 Okt0ber 2016

http://ornitologi.lk.ipb.ac.id / Broiler, Sejarah dan Perkembangannya / diakses tanggal 14 Oktober 2016 